\title{
Use of an estuarine environment (Barra do Saí lagoon, Brazil) as nursery by fish ${ }^{1}$
}

\author{
Ana L Vendel ${ }^{2} \&$ Paulo de T. Chaves ${ }^{3}$ \\ ${ }^{1}$ Contribution number 1660 of the Departamento de Zoologia, Universidade Federal do Paraná. \\ ${ }^{2}$ Laboratório de Peixes, Ecologia e Conservação, Departamento de Sistemática e Ecologia, Universidade Federal da Paraíba. \\ 58059-900 João Pessoa, Paraíba, Brasil. CN Pq - LAPEC fellow. E-mail: genidens@ig.com.br \\ ${ }^{3}$ Departamento de Zoologia, Universidade Federal do Paraná. Caixa Postal 19020, 81531-980 Curitiba, Paraná, Brasil. \\ E-mail: ptchaves@ufpr.br
}

\begin{abstract}
Studies were carried out at the Barra do Saí lagoon, on the northern coast of Santa Catarina State, Brazil, to evaluate the function played by this estuary in the life cycle of fish found at the coastal zone. Samplings were performed using beach seine net from December 2000 to November 2001. The continental influence is strong, as showed by the occurrence of freshwater fishes, although most of the 43 species recorded are marine ones. It was verified that around summer, when the temperature of the water is high, the values of salinity decrease and those of turbidity increase. At this time there is also an increase in the abundance of juvenile fish in the lagoon. Because of its average depth of less than $0.7 \mathrm{~m}$, the lagoon is inhabited primarily by juveniles, which may enter either by active movement or passive displacement, originating from the sea or the river to which the lagoon is connected. The lagoon is not used for sheltering spawning individuals. It is showed that a shallow, small estuary with a blind bottom can conceal an importance for the coastal ichthyofauna that is greater than it could be expected from the occurrence - in this case, modest - of large individuals.
\end{abstract}

KEY WORDS. Coastal lagoon; fish assemblages; shallow waters; recruitment.

RESUMO. Utilização de um ambiente estuarino (Santa Catarina, Brasil) como berçário de peixes. A laguna de Barra do Saí, litoral norte de Santa Catarina, foi estudada para avaliar o papel desse estuário no ciclo de vida de peixes da zona costeira. Arrastos de praia foram realizados, e dados abióticos e de biometria foram obtidos, de dezembro de 2000 a novembro de 2001. No verão, quando a temperatura da água se eleva, diminuem os valores de salinidade e aumentam os de turbidez. A influência fluvial é corroborada pela ocorrência de espécies dulceaquíícolas, embora a maioria das 43 espécies registradas na laguna seja marinha. É também nesta época que aumenta a abundância de peixes jovens. $O$ sistema não se notabiliza por acolher indivíduos em desova: face à baixa profundidade, ele é habitado essencialmente pelos jovens, que possivelmente ingressam em movimentos ativos ou em deslocamento passivo, provenientes do mar e rio adjacentes. Demonstra-se que um estuário pequeno, raso e em fundo cego pode ter um importante papel nas fases iniciais do ciclo de vida de peixes costeiros, independentemente de ser utilizado por indivíduos adultos em reprodução.

PALAVRAS-CHAVE. Assembléias de peixes; áreas rasas; laguna; recrutamento.

Nursery and breeding activity have been the most valued attribute for evaluating the importance of an environment for fish, as showed by several authors (VANnUCCI 1999, PotTER et al. 2001, VIEIRA 2006). In this sense, the importance of estuaries as fish breeding areas has been classically associated to their utilization by spawning individuals or by those that complete their life cycles there or carry out migratory movements (BLABER 2000, PotTer et al. 2001, Vieira 2006). For juvenile of fish and decapod crustaceans, the term 'nursery' implies a special place where density, survival, and growth are enhanced over those in adjoining juvenile habitat types (SHERIDAN \& HAYS 2003).

Recognizing the function played by estuaries in the life cycle of fish is a base for using them adequately (HINDELL et al. 2000). In Barra do Saí, on the northern coast of Santa Catarina, a project is underway to deepen the lagoon in order to construct a passageway that would provide alternative access to the sea for the fishermen that inhabit there. Another project that foresees the utilization of the area for tourist ends, as the construction of an ecological park, is also underway. These environmental impacts, which are supposed to benegative to thelocal fauna, must beconstantly monitored because changes in estuarineconditions will, therefore, hold important implications for the dynamics of local coastal populations (Power \& ATTRILL 2002). The present study is the first ichthyofaunistic survey carried out in 
the Barra do Saí lagoon. It identifies the recurrent species in the habitat and helps to understand the role of this estuarine environment in the coastal ichthyofauna dynamics.

\section{MATERIAL AND METHODS}

The Barra do Saí lagoon (2559'S, 4836'W) is a well-preserved environmental with typical mangrove vegetation and, for now, without human occupation. It is maximum $2 \mathrm{~m}$ deep, has $1800 \mathrm{~m}$ longer and $30 \mathrm{~m}$ width, and is linked to the SaíGuaçu River, its only connection with sea, placed $800 \mathrm{~m}$ far from it (Fig. 1). Temperature, salinity and water transparency were measured in each sample point. Biological material was sampled at morning, from December 2000 (early summer) to November 2001 (end of spring), during waning moon tides of smaller amplitude, at six fixed points along the lagoon, equidistant 200 to $300 \mathrm{~m}$ (Fig. 1). Vegetation, granulometry and depth are homogeneous among the sample points.

Fish were obtained in a total of 72 fishing launches, using a beach seine of $22 \mathrm{~m}$ long, $2.5 \mathrm{~m}$ high, mesh size $5 \mathrm{~mm}$ between opposite knots. They were identified and measured (total length and mass) and classified with regard to gonad stage of development (VAzzoler 1996): A) imatures, B) maturation, C) ripe, and $D$ ) empty. Individuals in stage $A$ were considered young; in B, C or D, adult. Individuals C and D were considered as in reproductive activity.

Species richness, diversity (Shannon \& Weaver) and evenness (Pielou) were calculated monthly. The parametric analysis of variance (ANOVA) was used to find differences in the number of species because their values obey the normal distribution tested throughout Shapiro-Wilk's test. Non-parametric analysis (Kruskal-Wallis test) was applied to the number of individuals and biomass (total mass caught) between collections. In spite of the applied transformations to the variables, their values did not obey the normal distribution; non-parametric tests were then used in these analyses (ZAR 1996). A posteriori test of Student-Newman-Keuls was applied to the monthly captures. The hypothesis was that there are no differences regarding the number of species, individuals and biomass captured in the lagoon, between sampled points and months.

Specimens voucher are deposited in the ichthyological collection of the Museum of Natural History Capão da Imbuia, Curitiba, Paraná. Collection numbers M HNCl: 10009 to 10037.

\section{RESULTS}

The mean water temperature recorded varied from 18.7 \pm 0.89 ㅇ C (July) to $30.2 \pm 1.47$ 으 (March), with values above of 26으 from November to March and lower than 23ㄷ from May to August (Fig. 2). The salinity varied, on average, from $1.0 \pm$ 0.0 (February) to $30.7 \pm 1.03$ (August) (Fig. 3). The smallest mean values of water transparency $(25 \pm 3.76 \mathrm{~cm})$ were recorded in February, April, June and November; and the higher (70 \pm $22.49 \mathrm{~cm}$ ) in July, corresponding to the real mean depth at the sampled points (Fig. 4).

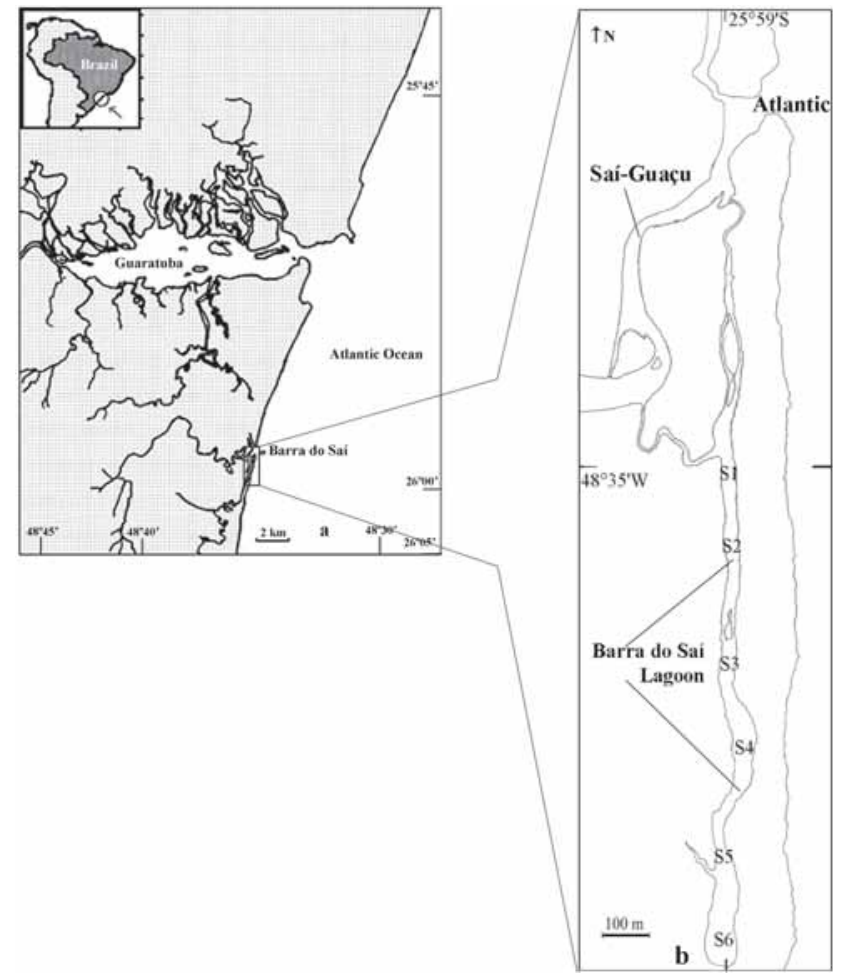

Figure 1. Study area: a) Barra do Saí lagoon on the Southern coast of Brazil; b) sampled points (S1 to S6) along the Barra do Saí lagoon.

A total of 4,132 individuals were captured, corresponding to 43 species of teleosts (Tab. I). Five species made up $62 \%$ of the total number of individuals: Eucinostomus argenteus (Baird \& Girard, 1855), E. melanopterus (Bleeker, 1863), Diapterus rhombeus (Cuvier, 1829), Atherinella brasiliensis (Quoy \& Gaimard 1825) and Centropomus parallelus Poey, 1860. From the remaining species, 28 occurred in proportionslesser than 1\% (Tab. I). Thefamilies with the highest number of species in the captures (five) were Gobiidae and Gerreidae.

Significant differences were not found between sample points ( $p>0.05$ ) in number of species, number of individuals and biomass. The highest number of species (23) was recorded at the end of spring and in summer (Fig. 5), and the highest number of individuals was captured in summer (Fig. 6). Thehighest biomass values were recorded in spring and summer, being the smallest value in January an exception (Fig. 7). The smallest number of species was recorded in winter (eight in July) as well as the smallest number of individuals (Figs 5 and 6). Significant differences were found between months $(p<0.05)$ for the number of species (higher values in December and March), number of individuals (higher values in January and March), and biomass (higher values in October and December). Mature individuals were found in $20 \%$ of species, including 44 gravid females in Poecilia vivipara Bloch \& Schneider 1801. However, juveniles 

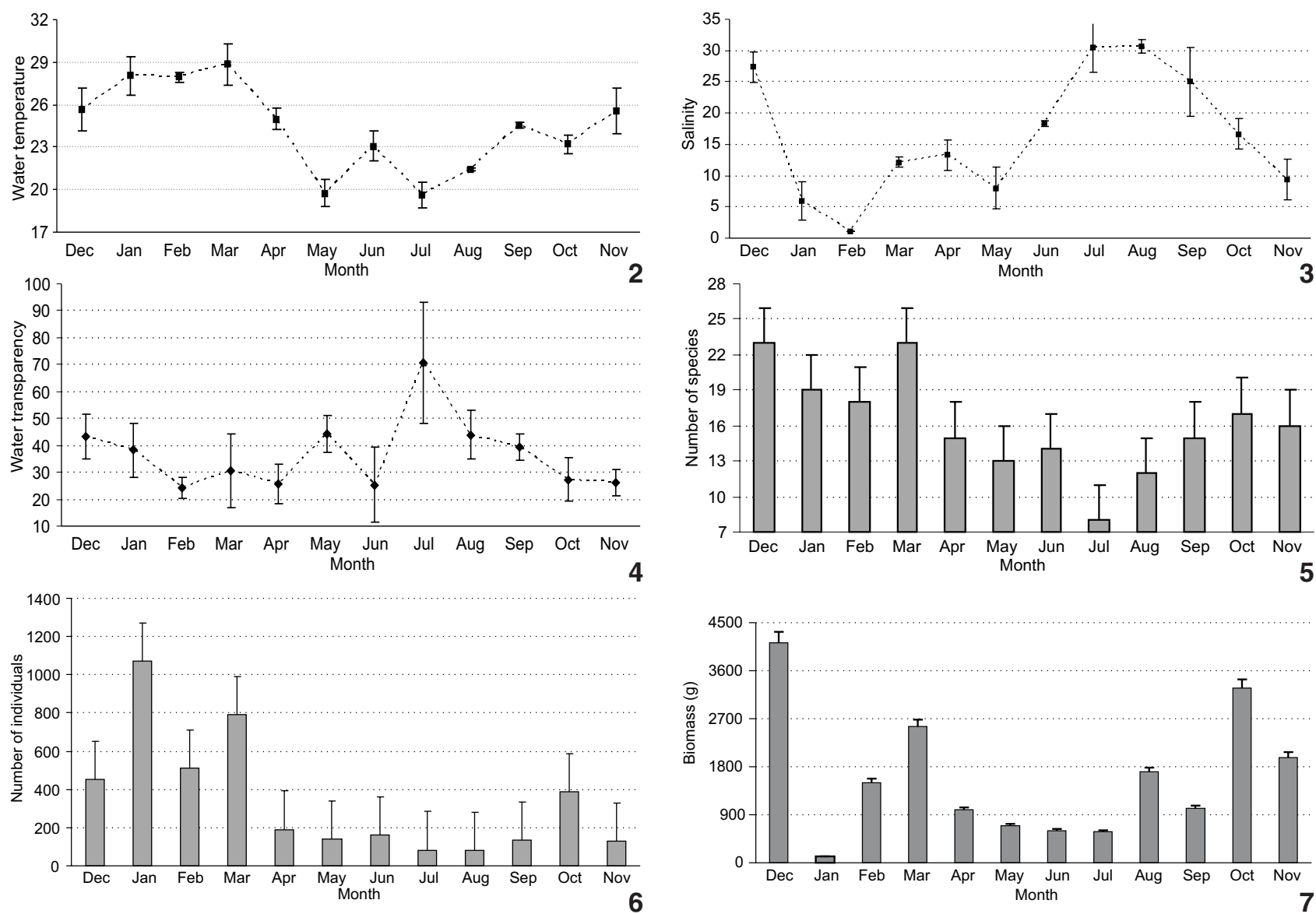

Figures 2-7. Monthly distribution of the mean values $( \pm \mathrm{SD})$ of: $(2)$ water temperature $\left({ }^{\circ} \mathrm{C}\right),(3)$ salinity $(\% \circ),(4)$ water transparency $(\mathrm{cm})$, the number of (5) species and (6) individuals caught, (7) biomass caught from December 2000 to November 2001 in Barra do Saí lagoon.

predominated, notably those of Sciaenidae, Engraulidae, Gerreidae, Clupeidae, Atherinopsidaeand Mugilidae, and in 50\% species only imatures - A stage - were found (Tab. I).

The highest value of species richness was recorded in January, whereas those of diversity and evenness in July (Fig. 8). Species of Mugilidae, Centropomidae, Gerreidae, Engraulidae, Atherinopsidae, Gobiidae and Tetraodontidae, as well as the flatfish Citharichthys arenaceus Evermann \& Marsh 1900, occurred constantly in the lagoon. Eight species - E. melanopterus, D. rhombeus, A. brasiliensis, C. parallelus, S. greeleyi Gilbert 1900, C. arenaceus, S. testudineus (Linnaeus, 1758) and Ctenogobius shufeldti (Jordan \& Eigenmann, 1887) - were present in all samples, months and points.

\section{DISCUSSION}

The strong changes registered in the salinity values along the year can be associated to the fact that this system constitutes a semi-isolated area, which is under direct influence of rainfall and of the connection with the Saí-Guaçu River. There-

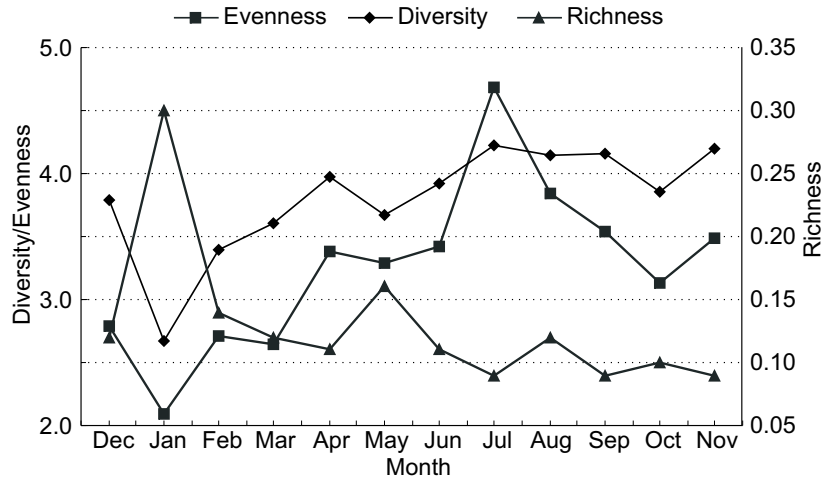

Figure 8. Evenness, diversity and species richness values in Barra do Saí lagoon according to the sampling month.

fore, the months around summer have the highest values of temperature, but also the lowest values of transparency and salinity, which enables the occurrence of freshwater species. 
Table I. Taxa of the individuals caught with beach seine in Barra do Saí lagoon from December 2000 to November 2001. Total number of individuals (n), percentage of the total capture (\%), total biomass (B) and gonad stages (G.S.).

\begin{tabular}{|c|c|c|c|c|c|}
\hline Family & Species & $\mathrm{n}$ & $\%$ & $B(g)$ & G.S. \\
\hline \multirow[t]{2}{*}{ Engraulidae } & Anchoa januaria (Steindachner, 1879) & 168 & 4.07 & 199.83 & $A, B$ \\
\hline & Lycengraulis grossidens (Agassiz, 1829) & 1 & 0.02 & 11.96 & $A$ \\
\hline Clupeidae & Harengula clupeola (Cuvier, 1829) & 1 & 0.02 & 0.68 & $A$ \\
\hline Ariidae & Genidens genidens (Cuvier, 1829) & 16 & 0.39 & 994.38 & $A, B$ \\
\hline \multirow{3}{*}{ Mugilidae } & Mugil curema Valenciennes, 1836 & 132 & 3.19 & 1557.92 & $A$ \\
\hline & Mugil platanus Gunther, 1880 & 61 & 1.48 & 657.58 & $A$ \\
\hline & Mugil sp. & 28 & 0.68 & 90.67 & A \\
\hline Atherinopsidae & Atherinella brasiliensis (Quoy \& Gaimard, 1825) & 483 & 11.69 & 2454.15 & $A, B, C, D$ \\
\hline \multirow[t]{2}{*}{ Belonidae } & Strongylura marina (Walbaum, 1792) & 78 & 1.89 & 807.77 & $A, B, C$ \\
\hline & Strongylura timucu (Walbaum, 1792) & 2 & 0.05 & 10.02 & A \\
\hline \multirow[t]{2}{*}{ Hemiramphidae } & Hemiramphus brasiliensis (Linnaeus, 1758) & 1 & 0.02 & 4.18 & A \\
\hline & Hyporhamphus unifasciatus (Ranzani, 1841) & 1 & 0.02 & 3.38 & $A$ \\
\hline \multirow[t]{2}{*}{ Centropomidae } & Centropomus parallelus Poey, 1860 & 359 & 8.69 & 1434.82 & $A, B$ \\
\hline & Centropomus undecimalis (Bloch, 1792) & 11 & 0.27 & 484.09 & A \\
\hline Cichlidae & Geophagus brasiliensis (Quoy \& Gaimard, 1824) & 2 & 0.05 & 360.83 & $A, B, C, D$ \\
\hline \multirow[t]{3}{*}{ Serranidae } & Epinephelus nigritus (Holbrook, 1855) & 4 & 0.10 & 53.45 & A \\
\hline & Epinephelus sp. & 1 & 0.02 & 0.27 & - \\
\hline & Mycteroperca sp. & 4 & 0.10 & 0.48 & - \\
\hline Poeciliidae & Poecilia vivipara Bloch \& Schneider, 1801 & 66 & 1.60 & 202.50 & $A$ \\
\hline \multirow[t]{2}{*}{ Carangidae } & Caranx latus Agassiz, 1831 & 1 & 0.02 & 9.79 & A \\
\hline & Oligoplites saurus (Bloch \& Schneider, 1801) & 2 & 0.05 & 7.18 & A \\
\hline \multirow[t]{5}{*}{ Gerreidae } & Diapterus rhombeus (Cuvier, 1829) & 490 & 11.86 & 2885.43 & $A, B$ \\
\hline & Eucinostomus argenteus Baird \& Girard, 1855 & 688 & 16.65 & 556.04 & A \\
\hline & Eucinostomus gula (Quoy \& Gaimard, 1824) & 3 & 0.07 & 14.47 & $A$ \\
\hline & Eucinostomus melanopterus (Bleeker, 1863) & 530 & 12.83 & 640.19 & A \\
\hline & Eugerres brasilianus (Cuvier, 1830) & 5 & 0.12 & 78.09 & $A$ \\
\hline \multirow[t]{2}{*}{ Sciaenidae } & Micropogonias furnieri (Desmarest, 1823) & 2 & 0.05 & 17.91 & A \\
\hline & Ophioscion punctatissimus Meek \& Hildebrand, 1925 & 1 & 0.02 & 1.56 & A \\
\hline \multirow[t]{5}{*}{ Gobiidae } & Bathygobius soporator (Valenciennes, 1837) & 114 & 2.76 & 508.68 & $A, B, C, D$ \\
\hline & Ctenogobius oceanicus (Pallas, 1770) & 10 & 0.24 & 89.06 & B \\
\hline & Ctenogobius shufeldti (Jordan \& Eigenmann, 1887) & 254 & 6.15 & 269.17 & $A, B, C, D$ \\
\hline & Ctenogobius smaragdus (Valenciennes, 1837) & 34 & 0.82 & 72.72 & $A, B, C, D$ \\
\hline & Gobionellus stomatus Starks, 1913 & 8 & 0.19 & 17.45 & $\mathrm{C}$ \\
\hline Eleotridae & Guavina guavina (Valenciennes, 1837) & 1 & 0.02 & 5.57 & $\mathrm{~B}$ \\
\hline \multirow[t]{2}{*}{ Paralichthyidae } & Citharichthys arenaceus Evermann \& Marsh, 1900 & 194 & 4.70 & 445.37 & $A, B$ \\
\hline & Citharichthys spilopterus Günther, 1862 & 41 & 0.99 & 511.79 & $A, B$ \\
\hline \multirow[t]{3}{*}{ Achiridae } & Achirus declivis Chabanaud, 1940 & 4 & 0.10 & 5.71 & A \\
\hline & Achirus lineatus (Linnaeus, 1758) & 20 & 0.48 & 29.63 & A \\
\hline & Trinectes microphthalmus (Chabanaud, 1928) & 1 & 0.02 & 0.21 & $A$ \\
\hline Cynoglossidae & Symphurus tessellatus (Quoy \& Gaimard, 1824) & 3 & 0.07 & 20.79 & $\mathrm{~B}$ \\
\hline Diodontidae & Cyclichthys spinosus (Linnaeus, 1758) & 3 & 0.07 & 44.97 & - \\
\hline \multirow[t]{2}{*}{ Tetraodontidae } & Sphoeroides greeleyi Gilbert, 1900 & 100 & 2.42 & 862.34 & $A, B, C, D$ \\
\hline & Sphoeroides testudineus (Linnaeus, 1758) & 204 & 4.94 & 3791.27 & $A, B, C, D$ \\
\hline Total & & 4,132 & 100.00 & $20,214.35$ & \\
\hline
\end{tabular}

Revista Brasileira de Zoologia 23 (4): 1117-1122, dezembro 2006 
The ichthyofauna, if considered within the limited area of the lagoon, is made up of a large number of species. Its homogeneous distribution throughout the lagoon agrees with the spatial uniformity of the abiotic variables studied. The temporal coincidence registered between lower captures in biomass and higher captures in number indicates that at the beginning of summer recruitment occurs in the lagoon. This phenomenon explains also the small values of diversity and evenness found at that time. Since only a few species had adults in their composition, and an even smaller number of species showed breeding activity in the lagoon, it is evident the use of this system by individuals in the early phases of their life cycle. Larvae and juveniles arrive in thelagoon probably through their own movements; eggs, carried by the incoming tide. Consequently, the Barra do Saí lagoon plays a role of shallow salt marsh creeks as refuges for juvenile fish (PATERSON \& W HitField 2000).

The families registered in this study and the relative abundance between them correspond to those described for shalIow waters in other regions of the Western Atlantic (VIEIRA \& Musick 1993, Pessanha \& Araújo 2003). The high number of species of a marine origin, compared to the reduced number of freshwater species, confirms the strong marine influence that dominates the Barra do Saí lagoon, despite the proximity of Saí-Guaçu River. However, the occurrence of two species of freshwater origin - Poecilia vivipara and Geophagus brasiliensis (Quoy \& Gaimard, 1824) - illustrates the fluvial proximity. The former of these species seems to use the lagoon for spawning.

The structural indices of a community are directly re lated to the size of the studied region and the fish effort employed during the surveys (GIBson 1999). In the present study, the diversity and evenness values presented changes along the year. This fact can be associated to the incoming of waters from a different origin, fluvial or marine according to the season. This attributes propitiated the access of marine inhabitants (Serranidae and Achiridae) in addition to some freshwaters species (P. vivipara and G. brasiliensis). Also, as noted by (KENNISH 1990), the diversity patterns are strongly influenced by the dynamics of local populations. Thus, in winter the lower values of diversity and evenness reflected in Barra do Saí lagoon an important number of individuals distributed in a few number of species. A similar pattern was described by Vendel et al. (2003) in shallow waters adjacent to the Paranaguá bay, $40 \mathrm{~km}$ far from Barra do Saí lagoon.

In the present study, the species richness value was expressive if considered the reduced area of the lagoon. This fact supports the hypothesis of nursery it plays, despite the modest spawning activity. In the same way, PATERSON \& W HITFIELD (2000) conclude that shallow estuarine areas containing fish assemblages with high proportions of juvenile individuals may provide refuge for life-stages vulnerable to predation. The importance of the lagoon is clear by the number of species that inhabit this area and by the nursery use made of it, mainly for species (Mugilidae, Centropomidae, Carangidae, Sciaenidae) target by commercial fisheries in the marine, adjacent waters (Robert \& Chaves 2006). Since the environment is semi-isolated and very shallow when compared to bay-like estuaries, the access of large fish into Barra do Saí is limited. This is a special case where the use of an estuary for reproduction is not associated to the actual spawning, as in Guaratuba Bay (CHAVES \& BOUCHEREAU 2000), but to the growth of individuals at the early phases of development.

\section{ACKNOWLEDGEMENTS}

To Kelly Aguiar, Eveline Ferreira, Wilson Soares, Luciano Costa, Luciana Fuzetti and Juliana de Pina (UFPR); José Lima deFigueiredo (USP); Bruno Bellini (UFPB); Jean-Luc Bouchereau and Yann Frejaville (Université des Antilles et de la Guyane); and to CNPq (financial support) and Pós-Graduação ZoologiaUFPR.

\section{REFERENCES}

BLABER, S.J.M. 2000. Tropical estuarine fishes. Ecology, exploitation and conservation. Oxford, Blackwell Science, 372p.

Chaves, P.T.C. \& J.-L. Bouchereau. 2000. Use of mangrove habitat for reproductive activity by the fish assemblage in the Guaratuba Bay, Brazil. Oceanologica Acta, Brest 23 (3): 273 280.

GiBSON, R.N. 1999. Methods for Studying Intertidal Fishes, p. 725. In: M.H. HoRn; K.L.M. MARTIN \& M.A. ChotKowSKI (Eds). Intertidal fishes life in two worlds. San Diego, Academic Press, XIV+399p.

Hindell, J.S.; P.J. Gregory \& M.J. Keough. 2000. Evaluating the impact of predation by fish on the assemblage structure of fishes associated with seagrass (Heterozostera tasmanica) (Martens ex Ascherson) den Hartog, and unvegetated sand habitats. Journal of Experimental Marine Biology and Ecology, Oxford, 255: 153-174.

KeNNISH, M. J. 1990. Ecology of estuaries. Boston, CRC Press, $391 p$.

Legendre, L. \& P. Legendre. 1984. Ecologie numérique: le traitement multiple des données écologiques. Paris, Masson PUQ, 270p.

Paterson, A.W. \& A.K. Whitfield. 2000. Do shallow-water habitats function as refugia for juvenile fishes? Estuarine, Coastal and Shelf Science, Oxford, 51: 359-364.

Pessanha, A.L.M. \& F.G. Araújo. 2003. Spatial, temporal and diel variations of fish assemblages at two sandy beaches in the Sepetiba Bay, Rio de Janeiro, Brazil. Estuarine, Coastal and Shelf Science, Oxford 57: 817-828.

Potter, I.C.; D.J. Bird; P.N. Claridge; K.R. Clarke; G.A. Hyndes \& L.C. Newton. 2001. Fish fauna of the Severn Estuary. Are there long-term changes in abundance and species composition and are the recruitment patterns of the main marine species correlated? Journal of Experimental Marine Biology and Ecology, Oxford, 258:15-37. 
Power, M. \& M.J. Attrill. 2002. Factors affecting long-term trends in the estuarine abundance of pogge (Agonus cataphractus). Estuarine, Coastal and Shelf Science, Oxford 54: 941-949.

Robert, M.C. \& P.T. Chaves. 2006. Dinâmica da atividade pesqueira artesanal em duas comunidades da região litorânea limítrofe Santa Catarina-Paraná, Brasil. Boletim do Instituto de Pesca, São Paulo 32 (1): 15-23.

SHeRIDAN, P. \& C. HAYS. 2003. Are mangroves nursery habitat for transient fishes and decapods? Wetlands, Georgia, 23 (2): 449-458.

VANNUCCI, M. 1999. Osmanguezaise nós. São Paulo, Ed. EDUSP, $233 p$.

Vazzoler, A.E.M. 1996. Biologia da reprodução de peixes

Received in 14.VII.2006; accepted in 31.X.2006. teleósteos: teoria e prática. Maringá, Ed. EDUEM, 169p.

Vendel, A.L.; H.L. Spach: S.G. Lopes \& C. Santos. 2003. Fish assemblage in a tidal flat. Brazilian Archives of Biology and Technology, Curitiba 46 (2): 233-242.

VIEIRA, J.P. 2006. Ecological anal ogies between estuarine bottom trawl fish assemblages from Patos Lagoon, Rio Grande do Sul, Brazil and York River, Virginia, USA. Revista Brasileira de Zoologia, Curitiba, 23 (1): 234-247.

VIEIRA, J.P. \& J.A. Musick. 1993. Latitudinal patterns in diversity of fishes in warm-temperate and tropical estuarine waters of the Western Atlantic. Atlântica, Rio Grande, 15: 115133.

ZAR, J.H. 1996. Biostatistical analyses. Upper Sadle River, Prentice-Hall, 660p. 